\title{
The Biology of Synovial Sarcoma: State-of-the-Art and Future Perspectives
}

Michele Fiore, $M D^{1}$

Andrea Sambri, $M D^{1,2, *}{ }^{*}$

Paolo Spinnato, $M D^{3}$

Riccardo Zucchini, $M D^{1}$

Claudio Giannini, $M D^{1}$

Emilia Caldari, $M D^{2}$

Maria Giulia Pirini, $M D^{2}$

Massimiliano De Paolis, $M D^{2}$

\author{
Address \\ ${ }^{1}$ Alma Mater Studiorum - University of Bologna, Bologna, Italy \\ ${ }^{*}, 2$ IRCCS Azienda Ospedaliero Universitaria di Bologna, via Massarenti 9, \\ 40138 Bologna, Italy \\ Email: andrea_sambri@libero.it \\ ${ }^{3}$ IRCCS Istituto Ortopedico Rizzoli, Bologna, Italy \\ Published online: 23 October 2021 \\ (๑) The Author(s) 2021
}

This article is part of the Topical Collection on Sarcoma

Keywords Synovial sarcoma diagnosis - Synovial sarcoma genomics - Sarcoma epigenomics - Synovial sarcoma treatment

\section{Opinion statement}

New molecular insights are being achieved in synovial sarcoma (SS) that can provide new potential diagnostic and prognostic markers as well as therapeutic targets. In particular, the advancement of research on epigenomics and gene regulation is promising. The concrete hypothesis that the pathogenesis of SS might mainly depend on the disruption of the balance of the complex interaction between epigenomic regulatory complexes and the 
consequences on gene expression opens interesting new perspectives. The standard of care for primary SS is wide surgical resection combined with radiation in selected cases. The role of chemotherapy is still under refinement and can be considered in patients at high risk of metastasis or in those with advanced disease. Cytotoxic chemotherapy (anthracyclines, ifosfamide, trabectedin, and pazopanib) is the treatment of choice, despite several possible side effects. Many possible drug-able targets have been identified. However, the impact of these strategies in improving SS outcome is still limited, thus making current and future research strongly needed to improve the survival of patients with SS.

\section{Introduction}

Synovial sarcoma (SS) is a malignant mesenchymal neoplasm [1, 2]. Multipotent mesenchymal stem cells have been considered as putative originators for several years, but SS origins are still unknown [3-7]. Synovial sarcoma accounts for 5 to $10 \%$ of all soft tissue sarcomas (STSs), and it predominantly occurs in older children and young adults $[2,8-10]$. In the pediatric population, SS is the most common non-rhabdomyosarcoma STS [11-13]. It is almost ubiquitarious, but its intra-articular occurrence is very uncommon [14, 15]. Synovial sarcoma can arise anywhere in the soft tissues, generally as a progressively expanding mass. The most common clinical presentation is a slow-growing lump in the soft tissues of the lower limb $(46.1 \%$ in the National Cancer Institute's Surveillance-NEER database $\left[16^{\bullet}\right]$ ), especially around the knee and the ankle. The head and neck region, abdominal wall, retroperitoneum, mediastinum, pleura, lungs, and other organs are less common locations.

Various symptoms may be related to different sites (such as difficulty in swallowing and breathing, or alteration of voice in the head and neck SS), although a painless swelling is the most frequent appearance. Pain may be related to the involvement of nerves or perilesional phlogosis in the advanced stages. Slow tumor growth and the apparent harmlessness of symptoms often lead to a delayed diagnosis.

Synovial sarcoma is characterized by local invasiveness and a propensity to metastasize. Nevertheless, at the time of diagnosis, less than $10 \%$ of cases present with metastases $[17,18]$. However, there is a high incidence of late metastases [17], reported in up to $50-70 \%$ of cases [19]. Most metastasis develop in the lungs $(80 \%)$, although bone $(9.9 \%)$ and liver $(4.5 \%)$ are the next most frequent locations [20]. While STS are known to primarily metastasize by hematogenous route to the lungs, lymph node metastasis is not uncommon in SS, with clinically detectable lymph node disease found in $1-27 \%$ of newly diagnosed patients [21-23]. Metastases were found to be more frequent in older patients [24].

\section{Imaging}

Radiographs show no pathological findings in approximately $50 \%$ of cases of SS, but eccentric or peripheral calcifications may be identified in up to $30 \%$ of cases $[12,25,26]$.

The ultrasound appearance of SS often reveals a focal, nodular, typically ovoid or slightly lobulated, solid but hypoechoic soft-tissue mass suggestive of an indolent process [27]. Prominent heterogeneity was reported in less than $20 \%$ of cases, with both homogeneous hypoechoic well-defined areas (reflecting cystic or necrotic change) and heterogeneous hyperechoic areas 
with irregular margins (corresponding to cellular areas of aggressive viable tumor, hemorrhage, calcification, or fibrosis) [27].

Computed tomography typically shows a heterogeneous, non-infiltrative mass with attenuation similar to or slightly lower than that of muscle [12, 28-31], often with punctate, peripheral calcifications [32, 33]. Calcifications may also be identified in metastasis, particularly in the lungs [33]. Heterogeneous post-contrast enhancement was reported in $89-100 \%$ of cases [29], helping to distinguish SS that initially appear as a cystic lesion or hematoma [32].

Synovial sarcoma has a variety of magnetic resonance imaging (MRI) appearances, ranging from small, homogenous nodules to large heterogeneous masses encasing vessels and nerves. One study found that $33 \%$ of SS were less than $5 \mathrm{~cm}$, and they had commonly benign imaging characteristics, with a predominantly homogeneous appearance on all MRI sequences [34]. On T1-weighted MRI images, SS typically appears as a heterogeneous multilobulated soft-tissue mass with signal intensity similar to or slightly higher than that of muscle [34-39]. Prominent heterogeneity ("triple sign") is reported in up to $57 \%$ of cases $[27,29,40]$. It is represented by intermixed areas of low, intermediate, and high signal intensity on long repetition time images, as the result of the mixture of solid cellular elements, hemorrhage or necrosis, and calcified or fibrotic regions (Fig. 1) [40]. However, the "triple sign" lacks in specificity, as it is also seen in other STS, particularly in malignant fibrous histiocytoma [12]. Areas of hemorrhage, seen as fluid-fluid levels or foci of high signal intensity on T1- and T2-weighted MRI, are frequent. Fluid levels have been described in $10-25 \%$ of SS in several series [12]. This combination of features, particularly largely cystic areas or prominent hemorrhagic foci, often creates a "bowl of grapes" appearance (Fig. 2) [41]. Areas of calcification remain low-to-intermediate signal intensity on all MRI. MRI typically

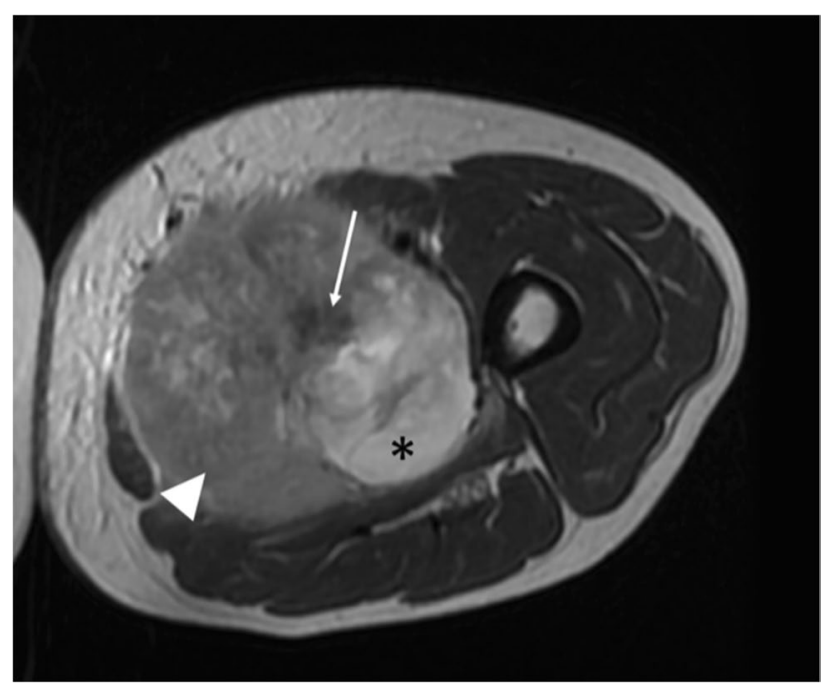

Fig. 1 T2w axial MRI of the left thigh in a 54-year-old male, affected by synovial sarcoma with multiple lung metastasis at diagnosis, showed a large inhomogeneous mass with the so-called "triple sign": fibrotic areas (low signal intensity arrow), solid cellular elements (intermediate signal — arrowhead), and hemorrhage/necrosis areas (high signal intensity — asterisks) 


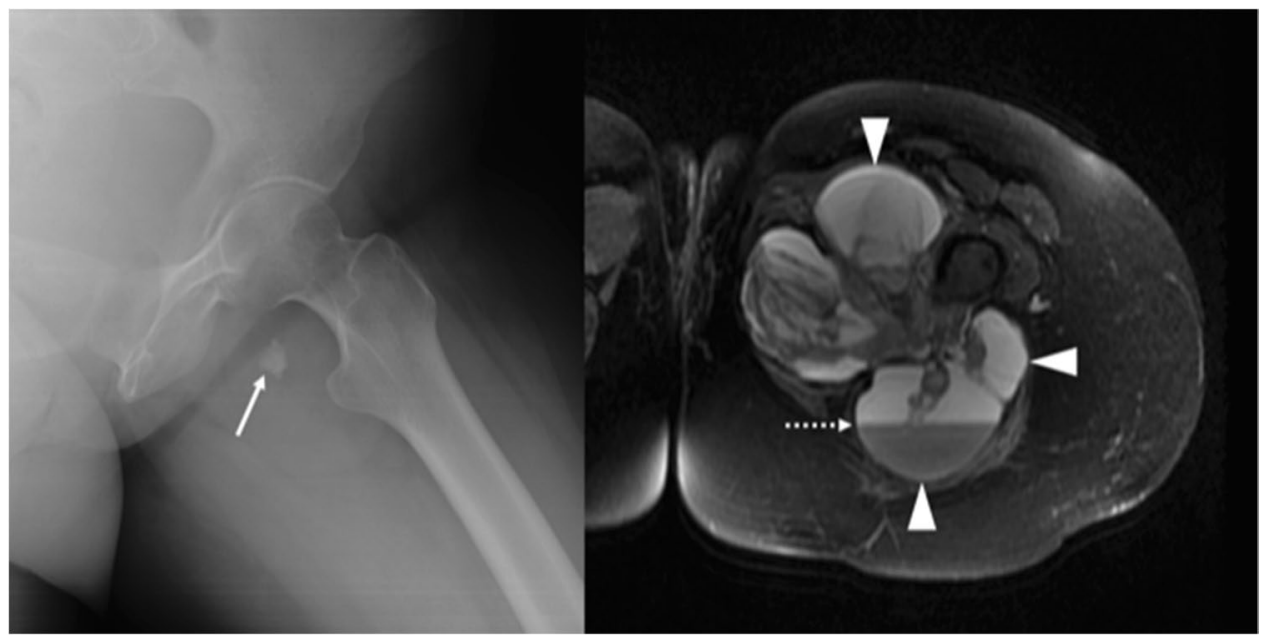

Fig. 2 Conventional radiograph (left) and T2w axial fat-saturated MRI (right) of the left thigh in 32-year-old female with synovial sarcoma, showed calcific area (arrow), and the so-called "bowl of grapes" appearance with rounded cystic necrotic/ hemorrhagic areas (arrowheads), containing a large fluid-fluid level (dotted arrow)

reveals conspicuous post-contrast enhancement in SS, usually heterogeneous, reflecting the intermixture of non-enhancing necrotic, cystic, or hemorrhagic regions and enhancing solid regions [39, 40].

Positron emission tomography (PET) of SS has been reported in few studies, but a marked increased tracer uptake was constantly described [42, 43].

Imaging may also play a role in prognostic assessment. In fact, several imaging features of SS have been found to be associated with poorer prognosis. In details, tumors larger than $5 \mathrm{~cm}$, located more proximally (upper thigh, inguinal region, head and neck, and trunk), lack of calcification, intra-tumoral hemorrhage, and the presence of "triple sign" were found to be significantly associated with worse disease-free survival [29]. Early gadolinium enhancement on MRI (within $7 \mathrm{~s}$ after arterial enhancement) was also found to be associated with a more aggressive behavior [44]. FDG-PET may also provide prognostic elements because pre-treatment SUV greater than 4.4 was found to be associated with an increased risk of local recurrence and metastatic disease [45].

Macroscopically, SSs are multinodular masses, highly variable in size. Calcifications are common features, but they can be difficult to discern grossly. Occasionally, there are smooth-walled cysts containing mucoid fluid or blood. Hemorrhage and necrosis can be prominent in poorly differentiated SS, although less than in high-grade pleomorphic sarcomas [46].

Microscopically, three distinct subtypes are recognized: monophasic, biphasic, and poorly differentiated $[47,48]$. Classification into subtypes is 
based upon somewhat subjective criteria, and there is a certain degree of overlap.

The monophasic type (the most common subtype) is composed of hypercellular arrays of small spindle cells with uniform, ovoid, vesicular nuclei with dispersed chromatin, inconspicuous nuclei, and very scarce amphophilic cytoplasm [2]. There is scarce intervening stroma, and the cells appear tightly packed. The stroma of SS can range from collagenous/ hyalinized, rarely with amianthoid fibers [49], to extensively myxoid. An increase in hyalinized stromal collagen may be seen in neoplasms recurring after radiation therapy (RT) [50]. A hemangiopericytic vascular pattern, with sparse, dilated, thin-walled vessels, is seen in approximately $60 \%$ of cases [51]. Mast cells are relatively a characteristic feature of SS, but the presence of other inflammatory cells is atypical [50]. The monophasic epithelioid subtype, in which the histologic pattern is uniformly glandular, is rarely characterized [52-54], and it is histologically often indistinguishable from adenocarcinoma, requiring molecular confirmation for diagnosis.

Biphasic SSs consist of a mixture of both fibroblast-like spindle cells (similar in appearance to those of the monophasic spindle cell subtype) and epithelial cells (often forming gland-like structures). Although the proportions of the two components fluctuate, often, they are approximately the same. The epithelial cells have round or ovoid vesicular nuclei, moderate amounts of amphophilic cytoplasm, and distinct cell borders. The classical architecture of the epithelial element consists of relatively well-formed glands with lumina containing mucin that can form papillary structures with cores containing spindled tumor cells rather than connective tissue [50]. However, the epithelial components can also appear less well differentiated, forming solid nests.

The poorly differentiated subtype is highly cellular and usually comprises sheets of small, rounded cells, with hyperchromatic nuclei and amphophilic cytoplasm, with frequent mitotic activity and necrosis. A poorly differentiated component can be seen focally within SS [55], or it can account for the entire tumor, thus resembling other small round cell neoplasms. Two other types of poorly differentiated SS have been recognized: a large cell epithelioid variant, with polygonal cells with abundant cytoplasm, and a high-grade pleomorphic spindle cell variant $[50,56]$. Poorly differentiated histology may occur more frequently in older adults [57].

Focal calcification, with or without ossification, is seen in approximately $30 \%$ of SS, more often in biphasic subtypes [50].

Synovial sarcoma has a differentiation score of 3, and it is therefore always a high-grade sarcoma (grade 2 or 3 ). Some authors proposed grading as an important prognostic factor [58]. 
oncogenes [59-63]. Nine SSX genes (SSX1-9) have been described which are highly homologous [64].

SS18-SSX can be detected in more than 95\% of SS [65], for which it is specific and has been seen in all morphologic subtypes. Approximately twothirds of SS harbor SS18- SSX1 gene fusions and one-third SS18-SSX2 [47, 64, 66, 67].

The specific gene fusion has been shown to correlate with tumor histology. Almost all biphasic SSs have been shown to harbor SS18-SSX1 fusions [66-68], and almost all of the SS18-SSX2 tumors show absence of glandular differentiation (monophasic histology) [66]. The rearrangement has been shown to be present in both (epithelial and spindle) cellular components of biphasic SS [69].

Recent data suggest that fusion type does not have prognostic value [47, 70], despite earlier studies suggesting that SS18-SSX1 produces more aggressive disease than SSX2 [47, 71-74].

Fluorescence in situ hybridization (FISH) using an SS18 break-apart probe is currently the most widely used approach to demonstrate the presumptive presence of one of the SS18-SSX fusions. However, other approaches including RT-PCR and, increasingly, massive parallel sequencing, are being more widely used [75]. Although highly specific, RT-PCR and SS18 break-apart FISH that are not perfect and have had reported sensitivities as low as 94\% and $83 \%$, respectively $[76,77]$. The use of both techniques has been recommended in the ancillary diagnosis of SS, giving at least $96 \%$ sensitivity and $100 \%$ specificity [55]. However, the rare cases of neoplasms morphologically and immunohistochemically typical of SS but without SS18-SSX fusions could represent tumors with unusual variant transcripts, which cannot be detected using routine molecular techniques [78].

Other than this translocation, SS tumors are mutationally quiet $[79,80]$. Despite this, metastatic SSs are associated with increased tumor genomic instability [81, 82].

\section{Epigenomic}

As mentioned above, the SS18-SSX fusion proteins are widely considered to be the main driver of SS pathogenesis [83, 84], as their expression is sufficient to induce SS tumors in mice [6,72], and their silencing causes SS cells to revert to mesenchymal stem cell-like cells [5].

Recent efforts have focused on unraveling the mechanism behind the SS18-SSX-mediated epigenetic rewiring, focusing on the interplay between the SS fusion protein and the chromatin remodeling machinery, in particular with regard to the two key protein complex families of epigenetic modifiers: SWItch/Sucrose NonFermentable (SWI/SNF) and Polycomb Repressive Complexes (PRC) $[79,85,86]$. While PRC leads to chromatin compaction and gene repression, SWI/SNF complexes facilitate transcription by remodeling nucleosomes, thereby promoting gene activation by permitting increased access of transcription factors to their binding sites [87]. 
The SWI/SNF or BRG1/BRM-associated factor (BAF) complexes are members of a family of Trithorax-group proteins (TrxG) [88, 89]. Only one of the three mammalian SWI/SNF complexes, the canonical BAF (cBAF) complex, contains SS18 and has been shown to interact with the SS fusion proteins. The SS18-SSX fusion proteins have been shown to competitively replace the wild-type SS18 in the CBAF complexes [90, 91], thus resulting in ejection of SWI/SNF-related matrix-associated actin-dependent regulator of chromatin subfamily B member 1 (SMARCB1) and its subsequent proteasome-mediated degradation $[92 \bullet \bullet$. These oncogenic BAF complexes are subsequently retargeted to PRC-repressed domains and have been shown to activate them [91], recruiting RNA Polymerase II to initiate transcription [93].

Another current theory is that the SS18-SSX oncoprotein mediates its transcriptional silencing via interaction with PRC1 and PRC2, since studies have shown SS18-SSX to co-localize with the complexes [94, 95]. The canonical PRC1 consists of two core subunits: RING1A/B and PCGF16. The PCGF components are important for maintaining the protein-protein interactions that initiate chromatin silencing $[96,97]$ and the knockdown of PCGF4 or either of the RING proteins, leading to a global reduction in PRC1 activity [98]. Concurrent with this, Barco et al. also found that the presence of SS18-SSX2 is associated with a downregulation of PCGF4 and subsequently with a decreased PRC1 activity [99]. There are also several heterogeneous non-canonical PRC1 complexes [86, 100]. In another proposed model, SS18-SSX utilizes lysine-specific demethylase 2B (KDM2B) as part of one of these non-canonical PRC1 (PRC1.1) to target CBAF to unmethylated CpG islands, generating a BAF-mediated PRC2 antagonism and aberrant gene activation at these sites [101]. PRC2 executes its chromatin silencing functions via its catalytic subunit Enhancer of Zeste 2 (EZH2), a histone methyltransferase [102]. SS18-SSX can serve a bridging function connecting activating transcription factor 2 (ATF2) to the PRC2 member transducin-like enhancer protein 1 (TLE1) and in doing so represses the expression of important tumor suppressor genes, including cyclin-dependent kinase inhibitor 2A (CDKN2A) and early growth response protein 1 (EGR1) [103-105].

There is currently no definitive theory for the pathogenesis of SS; however, the previous hypothesis shows that it could principally depend on the disruption of the balance of the complex interplay between the TrxG and PcG complexes. Therefore, a better understanding of the effects and consequences of the expression of SS18-SSX fusion proteins on the epigenomic regulators is needed $[91,106]$.

\section{Expression profile}

Gene expression studies have also shown several differences between SS18SSX1 and SS18-SSX2 fusion types, suggesting that these may lead to different downstream events [107].

Studies on the direct and indirect interactions of SS18-SSX oncoproteins suggest that they particularly affect cell growth and proliferation and have 
highlighted cyclin D1, Wnt/ $\beta$ catenin pathway components (LEF1, TCF7, ZIC2, WNT5A, AXIN2, and FZD10), TP53 pathway components, EGR1, insulin-like growth factor 2 together with its receptor IGF-1R, and chromatin remodeling mechanisms, as the most important targets of these oncoproteins contributing to sarcomagenesis [108].

However, an independent role might be played by the above-mentioned TLE1 gene (9q21.32), a member of the TLE family of genes that encode Groucho-like transcriptional corepressors. In fact, TLE1 is one of the most frequently overexpressed genes in SS [107, 109-111]. It binds other basic helix-loop-helix proteins to repress target genes [112-114] thus inhibiting the Wnt/ $\beta$ catenin signaling and other cell fate determination signals and have an established role in repressing differentiation $[115,116]$.

Other genes and pathways that exhibit perturbations in SS include Hedgehog (SMO, PTCH1), NY-ESO-1 (CTAG1A), and Notch (JAG1, JAG2, and HES1) and RTKs (FGF2, FGF3, EGFR, PDGFR, and IGFBP3) [111, 117, 118]. Moreover, the propensity for epithelial differentiation has been associated to the derepression of the transcription of E-cadherin [65]. Nevertheless, 21 different microRNAs (including let-7e, miR-99b, and miR-125a-3p) were found significantly upregulated in SS, suggesting that also these molecules have a potential oncogenic role [119].

Because these pathways and genes are not consistently affected in all cases, efforts have been made to identify a genetic signature that predicts survival or tumor progression [80]. For example, a downregulation of genes associated with neuronal and skeletal development and cell adhesion, as well as the upregulation of genes on the 8q21.11 locus, were identified in poorly differentiated SS [111]. However, further characterization of expression profiles is needed to identify possible prognostic factors and potential therapeutic targets.

\section{Immunohistochemistry}

A range of immunohistochemical (IHC) markers have been proposed to support the diagnosis of SS, most notably TLE1 [120]. However, to date, no single IHC marker or combination of markers can definitively confirm or exclude the diagnosis of SS [75]. Thus, despite FISH and molecular testing being expensive, not widely available, and time consuming in comparison to IHC, these approaches still represent the "gold standard" in SS diagnosis.

TLE1, due to its upregulation in SS, was identified from gene expression studies as a useful biomarker for distinguishing SS from other STSs [121]. TLE1 shows strong and diffuse nuclear staining in SS [116], with positive nuclear expression observed in more than $90 \%$ of cases [122, 123]. A recent systematic review examining the role of TLE1 as a diagnostic biomarker for SS found that the mean sensitivity and specificity of TLE1 in detecting SS were 94\% (95\% CI 91-97\%) and 81\% (95\% CI 72-91\%), respectively. The mean positive predictive value of TLE1 was $75 \%(95 \%$ CI $62-87 \%)$, whereas the negative predictive value was $96 \%(95 \% \mathrm{CI}$ 93-98\%) [118]. However, TLE1 expression has also been reported in up 
to one-third of non-SS [123], including potential mimics in differential diagnosis such as $17-20 \%$ of solitary fibrous tumors, $13-30 \%$ of malignant peripheral nerve sheath tumors, and $69 \%$ of malignant mesotheliomas [124] and, less commonly, 7\% of carcinomas [120, 122, 125-127]. Nuclear TLE1 expression is also observed in non-neoplastic tissues, with variable expression in basal keratinocytes, adipocytes, perineurial cells, endothelial cells, and mesothelial cells [122]. Therefore, particularly when its expression is moderate or strong, TLE1 is helpful in distinguishing SS from its histologic mimics; however, it should be used only in the context of a panel of antibodies (including keratins, EMA, CD34, and bcl-2) [120, 122].

NY-ESO-1, a cancer testis antigen, is also strongly and diffusely expressed in most SS (as in 76\% of tumors) but rarely in other mesenchymal lesions and may be useful in distinguishing SS from other spindle cell neoplasms [128, 129].

Brachyury transcription factor and CD34 are consistently negative in SS [130], while SMARCB1/INI1 protein expression was found to be reduced in $69 \%$ of cases, although no case with complete loss of expression was recognized [131, 132].

The diagnostic value of other markers has been limited by their lack of sensitivity and/or specificity. More than $90 \%$ of SS, including all histologic subtypes, show focal expression of epithelial markers cytokeratins and epithelial membrane antigen (EMA), with a characteristic patchy pattern in the spindle cell component and a more uniform staining in the epithelial component [133-135]. Cytokeratin subtypes CK7 and CK19 appear essentially restricted to SS and are helpful in their diagnosis [136-138]. As a significant number of SS are keratin positive but EMA negative or vice versa $[133,134]$, both markers should be used in a complementary manner. Other immunomarkers with some utility include carcinoembryonic antigen (CEA), vimentin, calponin, Bcl2, CD99, and S100 protein [80, $116,120-123,128,129,131,132,135,139-141]$.

Two new rabbit monoclonal antibodies have recently been developed and proposed to be highly sensitive and specific for the diagnosis of SS [142]: E9X9V (cat no 72364, Cell Signaling Technology, Danvers, MA USA) designed to recognize the SS18-SSX fusion proteins without cross reacting with wild-type SS18 or SSX proteins and E5A2C, and E5A2C (cat no 23855, Cell Signaling Technology, Danvers MA USA) designed to recognize the C-terminal end of the SSX1, SSX2 and SSX4 proteins [142]. If validated, these results could lead to introduce these antibodies in clinical practice to support SS diagnosis. with an overall survival (OS) rate of $87.3 \%$ at 1 year, $59.4 \%$ at 5 years, $50.8 \%$ at 10 years and $42.8 \%$ at 20 years follow-up, according to a recent large series [16 $]$. The difference between medium- to long-term survival reflects the fact 
that metastases in SS often occur very late, even beyond 10 years [17]. Patients with metastasis at diagnosis have a very poorer prognosis, with a 3-year survival rate of $27.2 \%$ [143].

Older patients, primary tumor located to the trunk, and large tumor size have been consistently reported to be associated with worse outcomes [24, $144,145]$. Tumor site can also affect prognosis, with a worse outcome for tumors arising from anatomic sites other than the extremities [41, 146-148].

Xiong et al. reported higher 5- and 10-year survival rates in the biphasic subtype (69\% and $60 \%$, respectively), followed by the monophasic subtype (59\% and 49\%, respectively) and lowest in the epithelioid subtype (32\% and $26 \%$, respectively) [149]. Bianchi et al. confirmed this observation, also reporting a worse survival in patients affected by FNLCC grade 3 SS than in those with grade 2 SS [58].

\section{Treatment}

Standard treatment of primary, localized SS is represented by wide surgical resection of the tumor. However, there is conflicting evidence regarding the systemic benefits of adjuvant RT [150-153]. Some prospective, randomized controlled studies on STS show evidence that adjuvant RT improves local control but not OS [151, 154, 155]. Specifically to SS, Rhomberg et al. observed that SS might be resistant to RT [156]. However, Seo et al. observed that RT is more effective in a subgroup with characteristics of old age (age $>20$ years), male patients, large tumors $(>5 \mathrm{~cm})$, extremity locations, early stages, and biphasic subtypes [157]. These data can partially support routine implementation of RT in the multimodality treatment of patients with SS [151].

The combination of RT combined with chemotherapy (ChT) can be significantly toxic, including risk of treatment-related deaths. Therefore, when treating patients with SS, clinicians may choose to forego RT and/or combination ChT with RT in favor of ChT alone as the combination of modalities increases toxicity and may lead to ChT dose reduction.

Cytotoxic ChT is often considered in both the neoadjuvant and adjuvant settings for patients with advanced SS [148]. Ferrari et al. reported 5-year, metastasis free survival rates of 60 and $40 \%$ for patients treated with and without ChT, respectively [158]. Edmonson et al. showed partial tumor regression in 5 of 12 patients with residual, recurrent, or metastatic tumors, with a median OS of 11 months [159].

Combined treatment with doxorubicin and ifosfamide represent front-line therapy for SS, with an expected response rate (RR) ranging between 25 and $60 \%$ [160-162]. For patients not amenable to anthracycline, single-agent high-dose ifosfamide is a valid alternative option, as it is in patients already pretreated with ifosfamide [163]. 
In some cases, ifosfamide monotherapy can be considered after this firstline combination treatment, in particular when there has been a reasonable interval between the end of first- and the start of second-line treatment. Single-center data on ifosfamide rechallenge in different STS subtypes showed the highest activity in SS [164]. In less fit patients, sequential doxorubicin and ifosfamide can be considered.

Recently, evofosfamide, a hypoxia-activated prodrug of bromo-isophosphoramide mustard, was evaluated within a randomized phase III trial in STS, which included patients with SS, who were randomly assigned to receive doxorubicin alone or doxorubicin plus evofosfamide. Evofosfamide showed an improvement in OS for the SS despite no evidence of survival benefit in the overall population [165].

An alternative treatment is the combination of gemcitabine and docetaxel, which may be considered in patients who cannot tolerate or are resistant to standard protocols. However, early studies suggested that gemcitabine, despite its effectiveness in STS, might not have much activity in SS [166, 167]. Similarly, in an early randomized study, patients receiving docetaxel exhibited no discernible responses [168, 169].

In second and later lines, trabectedin demonstrated antitumor effect in SS, with a 6-month progression-free survival (PFS) rate of $22 \%$ to $23 \%$ in two different retrospective studies and a 15\% RR [170, 171]. The mechanism of action is still being elucidated; it may affect transcription factors and tumor microenvironment through neoplastic macrophage depletion [172, 173].

Molecular targets

Tyrosine kinase inhibitors (TKIs) have some activity in SS, but pazopanib is the only one approved for treatment of STS. Pazopanib is an oral, multitargeted tyrosine kinase inhibitor directed against the receptor tyrosine kinases (RTKs) vascular endothelial growth factor receptors (VEGFR) $1 / 2 / 3$, platelet-derived growth factor receptors (PDGFR) $a / \beta$, and KIT, thereby blocking tumor growth and inhibiting angiogenesis. In the randomized phase III registration study, pazopanib was administered to 38 patients affected by SS and, compared with placebo, it improved the median PFS of 3 months (4.1 vs 1.0 month) [174-176]. Recent phase II and III studies suggest that pazopanib has activity in metastatic and refractory SS [177, 178]. Another TKI under investigation in STS is the multikinase VEGFR/PDGFR inhibitor regorafenib $[179,180]$. Finally, there are anecdotal reports on the activity of sorafenib and sunitinib and of bevacizumab combined with cediranib [181-183]. Although pazopanib and regorafenib were reported to significantly improve PFS compared with placebo in advanced SS patients, these treatment strategies did not improve the OS [179, 184, 185]. Apatinib is an oral anti-angiogenesis TKI, a highly and selective inhibitor on VEGFR with promising efficacy in advanced SS patients, although the evidence level of this study seems preliminary $[186 \bullet \bullet, 187,188]$. Other trials have been designed to inhibit specific targets in SS, in particular VEGF antibodies and the IGF-1R 
antibody cixutumumab [80, 189]. Olaratumab, a selective PDGFR monoclonal antibody, showed promising results in combined regimens [190]. In addition, PDGFR expression was recently reported in $84 \%$ of 44 SS tumor samples evaluated with immunostaining [191].

A new class of drugs able to inhibit EZH2 (the catalytic component of PRC2) is presently under investigation in tumors with BAF47/INI1 loss. The results of a phase II study of EZH2 inhibitor tazemetostat in the cohort of 33 patients with SS unluckily showed only a limited antitumor effect, with no objective responses and a 5-month median PFS [192].

Radiotherapy induces DNA double-strand breaks, stimulating DNA repair mechanisms, particularly those involving HDAC [193]. In preclinical studies, HDAC inhibitors induced differentiation, apoptosis, and growth arrest of SS cells while increasing tumor cell sensitivity to RT and ChT [103, 194, 195]. A phase II trial (NCT00112463) to study the efficacy of an HDAC inhibitor (romidepsin) in SS has recently closed to accrual, and results of the trial are pending [80].

Preclinical studies suggested several other actionable targets in SS, among which are the WNT-b-catenin and the protein kinase B (AKT)-mammalian target of rapamycin (mTOR) pathways, anaplastic lymphoma kinase (ALK), MET, and the cyclin D1-CDK4/6-Rb axis [117, 191, 196-200]. Moreover, various epigenomic regulators such as BCOR (a PRC1.1 component) [100] as well as SKP2 (an E3 ubiquitin ligase) were found to be overexpressed in undifferentiated SS, thus being a potential targetable gene [201].

However, despite the promising preclinical studies, the translation of these results to improved clinical outcomes remains challenging, and the benefit achieved from the introduction of new agents for management of advanced SS has been limited over the last decade.

Programmed death-1 protein (PD-1) is normally expressed on the surface of activated T-cells and suppresses unwanted or excessive immune responses, including autoimmune reactions. Its ligand PD-L1 can be expressed by various cells, including macrophages and tumor cells. The PD-1/PD-L1 interaction is a major pathway used by tumors to suppress immune control. Several studies have assessed the expression of PD-L1 in sarcomas [202]. However, a recent study by Pollack et al. [203] demonstrated that among STS, SS has the lowest expression of PD-1/PD-L1 and the lowest T-cell infiltration [204]. This explains different trials with pembrolizumab, ipilimumab, and nivolumab demonstrated no activity of cytotoxic T-lymphocyte antigen 4 (CTLA4) or PD-1 inhibition for the treatment of SS [205, 206]. Nonetheless, Jerby-Arnon et al. recently reported a novel "core oncogenic program" driven by SS18SSX, with implications for treatment strategies based on epigenetics, cell-cycle control, and immune augmentation [204]. Therefore, further studies might examine whether HDAC and CDK4/6 inhibitors could induce T-cell priming and recruitment due to cell damage and test potential synergies with different forms of cancer immunotherapies, such as immune checkpoint blockade, 
adoptive T-cell therapies, or cancer vaccines. Several clinical trials evaluating the efficacy of these new therapeutic approaches are currently ongoing. Thus far, it has been reported that trials with more targeted immunotherapies against tumor-specific antigens have shown greater promise in SS, in particular vaccines that trigger priming of NY-ESO-1-specific T-cell response [207], as well as therapies based on autologous T-cells transduced with a T-cell receptor directed against NY-ESO-1 [208].

\section{Metabolic therapy}

Arginino-succinate synthetase 1 (ASS1) is the rate-limited enzyme in the urea cycle responsible for the formation of arginine-succinate from citrulline and aspartate. When ASS1 is not expressed, cells are reliant on extracellular sources of the aminoacid arginine. Loss of expression of ASS1 due to methylation has been demonstrated to be the most common defect among STS, including SS [209]. This loss makes SS an attractive cancer for treatment with arginine starvation with agents such as pegylated arginine deiminase [210]. Arginine starvation alters SS metabolism and glutathione levels, making it more sensitive to treatment with ChT [210]. This metabolic defect is under development as the basis for a multiagent biomarker-driven metabolic therapy for SS.

\section{Conclusions}

Substantial advances in the understanding of the natural history and pathogenesis of SS have been made. However, the prognosis is still scarce.

The standard of care for primary SS is wide surgical resection combined with RT in selected cases. The role of ChT is still under refinement and can be considered in patients at high risk of metastasis or in those with advanced disease. Cytotoxic ChT (anthracyclines, ifosfamide, trabectedin, and pazopanib) are the treatments of choice, despite several possible side effects. Many possible drug-able targets have been identified. However, the impact of these strategies in improving SS outcome is still limited, thus making current and future research strongly needed to improve the survival of patients with SS.

\section{Author Contribution}

Massimiliano De Paolis, Andrea Sambri and Michele Fiore conceived the study and revised the paper; Michele Fiore, Andrea Sambri and Paolo Spinnato drafted the manuscript and collected and interpreted the data; Riccardo Zucchini, Claudio Giannini, Maria Giulia Pirini and Emilia Caldari participated in planning and revising the manuscript. All the authors read and approved the final manuscript. 


\section{Funding}

Open access funding provided by Alma Mater Studiorum - Università di Bologna within the CRUI-CARE Agreement.

\section{Declarations}

\section{Ethics Approval}

the institutional review board of our hospital has confirmed that no ethical approval is required for this study.

\section{Consent to Participate}

Not applicable.

\section{Consent for Publication \\ Not applicable.}

\section{Conflict of Interest}

Michele Fiore declares that he has no conflict of interest. Andrea Sambri declares that he has no conflict of interest. Paolo Spinnato declares that he has no conflict of interest. Riccardo Zucchini declares that he has no conflict of interest. Claudio Giannini declares that he has no conflict of interest. Emilia Caldari declares that she has no conflict of interest. Maria Giulia Pirini declares that she has no conflict of interest. Massimiliano De Paolis declares that he has no conflict of interest.

Open Access This article is licensed under a Creative Commons Attribution 4.0 International License, which permits use, sharing, adaptation, distribution and reproduction in any medium or format, as long as you give appropriate credit to the original author(s) and the source, provide a link to the Creative Commons licence, and indicate if changes were made. The images or other third party material in this article are included in the article's Creative Commons licence, unless indicated otherwise in a credit line to the material. If material is not included in the article's Creative Commons licence and your intended use is not permitted by statutory regulation or exceeds the permitted use, you will need to obtain permission directly from the copyright holder. To view a copy of this licence, visit http://creativecommons.org/licenses/by/4.0/.

\section{References and Recommended Reading}

Papers of particular interest, published recently, have been

highlighted ass:

- Of importance

-• Of major importance

1. Fisher C. Synovial sarcoma. Ann Diagn Pathol. 2. 1999;2:401-21.

Thway K, Fisher C. Synovial sarcoma: defining features and diagnostic evolution. Ann Diagn Pathol United States. 2014;18:369-80. 
3. Ishibe T, Nakayama T, Aoyama T, Nakamura T, Toguchida J. Neuronal differentiation of synovial sarcoma and its therapeutic application. Clin Orthop Relat Res. 2008;466:2147-55. Available from: https://doi.org/10. 1007/s11999-008-0343-z.

4. Garcia C, Shaffer CM, Alfaro M, Smith A, Sun J, Zhao $\mathrm{Z}$, et al. Reprogramming of mesenchymal stem cells by the synovial sarcoma-associated oncogene SYT-SSX2. Oncogene. 2011;31:2323-34.

5. Naka N, Takenaka S, Araki N, Miwa T, Hashimoto N, 18. Yoshioka K, et al. Synovial sarcoma is a stem cell malignancy. Stem Cells. 2010;28:1119-31.

6. Haldar M, Hancock JD, Coffin CM, Lessnick SL, Capecchi MR. A conditional mouse model of synovial sarcoma: insights into a myogenic origin. Cancer Cell. 2007;11:375-88. Available from: http://www.sciencedir ect.com/science/article/pii/S1535610807000323.

7. Riggi N, Cironi L, Stamenkovic I. Synovial sarcoma: 20. when epigenetic changes dictate tumour development. Swiss Med Wkly Switzerland. 2018;148:14667.

8. Sultan I, Rodriguez-Galindo C, Saab R, Yaser S, Casanova $\mathrm{M}$, Ferrari A. Comparing children and adults with synovial sarcoma in the surveillance, epidemiology, and end results program, 1983 to 2005 an analysis of 1268 patients. Cancer. 2009;115:3537-47.

9. Shi W, Morris CG, Zlotecki RA. Long-term outcomes for synovial sarcoma treated with surgery and radiotherapy: The University of Florida Experience. Int J Radiat Oncol 22. Biol Phys. Elsevier; 2009;75:S529. Available from: https://doi.org/10.1016/j.ijrobp.2009.07.1207.

10. Herzog CE. Overview of sarcomas in the adolescent and young adult population. J Pediatr Hematol Oncol 23. [Internet]. 2005;27. Available from: https://journals. lww.com/jpho-online/Fulltext/2005/04000/Overview_ of_Sarcomas_in_the_Adolescent_and_Young.9.aspx

11. Gurney JG, Young JL, Roffers SD, Smith MA, Bunin GR. 24. Soft tissue sarcomas. In: Ries LAG, Smith MA, Gurney JG, Linet M, Tamra T, Young JL, et al., editors. Cancer Incid Surviv among Child adoles- cents United States SEER Progr 1975-1995. Bethesda: National Cancer Institute: NIH Pub. No. 99-4649; 1999. p. 112-23.

12. Murphey MD, Gibson MS, Jennings BT, Crespo-Rodríguez 25. AM, Fanburg-Smith J, Gajewski DA. From the archives of the AFIP: imaging of synovial sarcoma with radiologicpathologic correlation. Radiogr a Rev Publ Radiol Soc 26. North Am Inc. United States; 2006;26:1543-65.

13. Sambri A, Bianchi G, Cucurnia I, Gambarotti M, Donati DM. Pediatric soft tissue sarcoma of the limbs: clinical 27. outcome of 97 patients. Eur J Orthop Surg Traumatol France. 2018;28:1-7.

14. McKinney C, Mills S, Fechner R. Intraarticular synovial 28. sarcoma. Am J Surg Pathol. 1992;16:1017-20.

15. Spillane AJ, A'Hern R, Judson IR, Fisher C, Thomas JM. Synovial sarcoma: a clinicopathologic, staging, and 29. prognostic assessment. J Clin Oncol Off J Am Soc Clin Oncol United States; 2000;18:3794-803.

16. Aytekin MN, Öztürk R, Amer K, Yapar A. Epidemiology, incidence, and survival of synovial sarcoma subtypes: SEER database analysis. J Orthop Surg (Hong Kong). England; 2020;28:2309499020936009.

The largest reported series providing epidemiologic data on Synovial Sarcoma.

17. Krieg AH, Hefti F, Speth BM, Jundt G, Guillou L, Exner UG, et al. Synovial sarcomas usually metastasize after $>5$ years: a multicenter retrospective analysis with minimum follow-up of 10 years for survivors. Ann Oncol Off J Eur Soc Med Oncol England. 2011;22:458-67. de Necochea-Campion R, Zuckerman LM, Mirshahidi HR, Khosrowpour S, Chen C-S, Mirshahidi S. Metastatic biomarkers in synovial sarcoma. Biomark Res. 2017;5:4. Singer S, Baldini EH, Demetri GD, Fletcher JA, Corson JM. Synovial sarcoma: prognostic significance of tumor size, margin of resection, and mitotic activity for survival. J Clin Oncol Off J Am Soc Clin Oncol United States. $1996 ; 14: 1201-8$.

Vlenterie M, Litière S, Rizzo E, Marréaud S, Judson I, Gelderblom H, et al. Outcome of chemotherapy in advanced synovial sarcoma patients: review of 15 clinical trials from the European Organisation for Research and Treatment of Cancer Soft Tissue and Bone Sarcoma Group; setting a new landmark for studies in this entity. Eur J Cancer England. 2016;58:62-72.

21. Amankwah EK, Conley AP, Reed DR. Epidemiology and therapies for metastatic sarcoma. Clin Epidemiol. 2013;5:147-62.

Rosenthal J, Cardona K, Sayyid SK, Perricone AJ, Reimer $\mathrm{N}$, Monson D, et al. Nodal metastases of soft tissue sarcomas: risk factors, imaging findings, and implications. Skeletal Radiol Germany. 2020;49:221-9.

Brodsky JT, Burt ME, Hajdu SI, Casper ES, Brennan MF. Tendosynovial sarcoma. Clinicopathologic features, treatment, and prognosis. Cancer United States. 1992;70:484-9.

Scheer M, Blank B, Bauer S, Vokuhl C, Stegmaier S, Feuchtgruber S, et al. Synovial sarcoma disease characteristics and primary tumor sites differ between patient age groups: a report of the Cooperative Weichteilsarkom Studiengruppe (CWS). J Cancer Res Clin Oncol Germany. 2020;146:953-60.

Horowitz AL, Resnick D, Watson RC. The roentgen features of synovial sarcomas. Clin Radiol England. 1973;24:481-4.

Wilkerson BW, Crim JR, Hung M, Layfield LJ. Characterization of synovial sarcoma calcification. AJR Am J Roentgenol United States. 2012;199:W730-4.

Marzano L, Failoni S, Gallazzi M, Garbagna P. The role of diagnostic imaging in synovial sarcoma. Our experience Radiol Med Italy. 2004;107:533-40.

Israels SJ, Chan HS, Daneman A, Weitzman SS. Synovial sarcoma in childhood. AJR Am J Roentgenol United States. 1984;142:803-6.

Tateishi U, Hasegawa T, Beppu Y, Satake M, Moriyama $\mathrm{N}$. Synovial sarcoma of the soft tissues: prognostic significance of imaging features. J Comput Assist Tomogr United States. 2004;28:140-8. 
30. Ko SF, Chou FF, Huang CH, Ng SH, Wan YL, Lee TY, 46. et al. Primary synovial sarcoma of the gastrocolic ligament. Br J Radiol England. 1998;71:438-40.

31. Rangheard AS, Vanel D, Viala J, Schwaab G, Casiraghi 47. O, Sigal R. Synovial sarcomas of the head and neck: CT and MR imaging findings of eight patients. AJNR Am J Neuroradiol United States. 2001;22:851-7.

32. Nakanishi H, Araki N, Sawai Y, Kudawara I, Mano M, Ishiguro $\mathrm{S}$, et al. Cystic synovial sarcomas: imaging features with clinical and histopathologic correlation. 48 . Skeletal Radiol Germany. 2003;32:701-7.

33. Bakri A, Shinagare AB, Krajewski KM, Howard SA, Jagannathan JP, Hornick JL, et al. Synovial sarcoma: imaging features of common and uncommon primary sites, metastatic patterns, and treatment response. AJR Am J 49. Roentgenol United States. 2012;199:W208-15.

34. Blacksin MF, Siegel JR, Benevenia J, Aisner SC. Synovial sarcoma: frequency of nonaggressive MR characteristics. 50. J Comput Assist Tomogr United States. 1997;21:785-9.

35. Mahajan H, Lorigan JG, Shirkhoda A. Synovial sar- 51. coma: MR imaging. Magn Reson Imaging Netherlands. 1989;7:211-6.

36. Hirsch RJ, Yousem DM, Loevner LA, Montone KT, Chalian AA, Hayden RE, et al. Synovial sarcomas of the head and neck: MR findings. AJR Am J Roentgenol United 52. States. 1997;169:1185-8.

37. Sigal R, Chancelier MD, Luboinski B, Shapeero LG, Bosq J, Vanel D. Synovial sarcomas of the head and 53. neck: CT and MR findings. AJNR Am J Neuroradiol United States. 1992;13:1459-62.

38. Bernreuter WK, Sartoris DJ, Resnick D. Magnetic reso- 54. nance imaging of synovial sarcoma. J Foot Surg United States. 1990;29:94-100.

39. Morton MJ, Berquist TH, McLeod RA, Unni KK, Sim FH. 55. MR imaging of synovial sarcoma. AJR Am J Roentgenol United States. 1991;156:337-40.

40. Jones BC, Sundaram M, Kransdorf MJ. Synovial sarcoma: MR imaging findings in 34 patients. AJR Am J Roentgenol United States. 1993;161:827-30.

41. Wang DJ, Alwafi L, Pritchett SL, Wehrli BM, Spouge ARI. The imaging spectrum of synovial sarcomas: a pictorial 56 . review from a single-centre tertiary referral institution. Can Assoc Radiol J = J l'Association Can des Radiol. United States; 2020;846537119899284.

42. Nair N, Basu S. Unsuspected metastatic male breast nodule from synovial sarcoma detected by FDG PET. 57. Clin Nucl Med United States. 2005;30:289-90.

43. Sambri A, Bianchi G, Longhi A, Righi A, Donati DM, Nanni C, et al. The role of 18F-FDG PET/CT in soft tissue sarcoma. Nucl Med Commun England. 58. 2019;40:626-31.

44. van Rijswijk CS, Hogendoorn PC, Taminiau AH, Bloem JL. Synovial sarcoma: dynamic contrast-enhanced MR imaging features. Skeletal Radiol Germany. 2001;30:25-30.

45. Lisle JW, Eary JF, O'Sullivan J, Conrad EU. Risk assessment based on FDG-PET imaging in patients with synovial sarcoma. Clin Orthop Relat Res. 2008/12/02. Springer-Verlag; 2009;467:1605-11.
Smith MEF, Fisher C, Wilkinson LS, Edwards JCW. Synovial sarcomas lack synovial differentiation. Histopathology. John Wiley \& Sons, Ltd; 1995;26:279-81.

Guillou L, Benhattar J, Bonichon F, Gallagher G, Terrier P, Stauffer E, et al. Histologic grade, but not SYTSSX fusion type, is an important prognostic factor in patients with synovial sarcoma: a multicenter, retrospective analysis. J Clin Oncol Off J Am Soc Clin Oncol United States. 2004;22:4040-50.

Palmerini E, Benassi MS, Quattrini I, Pazzaglia L, Donati D, Benini S, et al. Prognostic and predictive role of CXCR4, IGF-1R and Ezrin expression in localized synovial sarcoma: is chemotaxis important to tumor response? Orphanet J Rare Dis. 2015;10:6.

Orenstein JM. Amianthoid fibers in a synovial sarcoma and a malignant schwannoma. Ultrastruct Pathol England. 1983;4:163-76.

Fisher C. Synovial sarcoma. Ann Diagn Pathol United States. 1998;2:401-21.

Tsuneyoshi M, Daimaru Y, Enjoji M. Malignant hemangiopericytoma and other sarcomas with hemangiopericytoma-like pattern. Pathol - Res Pract. 1984;178:44653. Available from: https://www.sciencedirect.com/ science/article/pii/S0344033884800047.

Farris KB, Reed RJ. Monophasic, glandular, synovial sarcomas and carcinomas of the soft tissues. Arch Pathol Lab Med United States. 1982;106:129-32.

Majeste RM, Beckman EN. Synovial sarcoma with an overwhelming epithelial component. Cancer United States. 1988;61:2527-31.

Weidner N, Goldman R, Johnston J. Epithelioid monophasic synovial sarcoma. Ultrastruct Pathol England. 1993; 17:287-94.

Amary MFC, Berisha F, Bernardi FDC, Herbert A, James M, Reis-Filho JS, et al. Detection of SS18-SSX fusion transcripts in formalin-fixed paraffin-embedded neoplasms: analysis of conventional RT-PCR, qRT-PCR and dual color FISH as diagnostic tools for synovial sarcoma. Mod Pathol an Off J United States Can Acad Pathol Inc United States. 2007;20:482-96.

van de Rijn M, Barr FG, Xiong QB, Hedges M, Shipley J, Fisher C. Poorly differentiated synovial sarcoma: an analysis of clinical, pathologic, and molecular genetic features. Am J Surg Pathol United States. 1999;23:106-12.

Chan JA, McMenamin ME, Fletcher CDM. Synovial sarcoma in older patients: clinicopathological analysis of 32 cases with emphasis on unusual histological features. Histopathology England. 2003;43:72-83.

Bianchi G, Sambri A, Righi A, Dei Tos AP, Picci P, Donati D. Histology and grading are important prognostic factors in synovial sarcoma. Eur J Surg Oncol J Eur Soc Surg Oncol Br Assoc Surg Oncol England. 2017;43:1733-9.

59. Skytting B, Nilsson G, Brodin B, Xie Y, Lundeberg J, Uhlén $\mathrm{M}$, et al. A novel fusion gene, SYT-SSX4, in synovial sarcoma. J Natl Cancer Inst. United States; 1999; 974-5. 
60. Smith S, Reeves BR, Wong L, Fisher C. A consistent 72. chromosome translocation in synovial sarcoma. Cancer Genet Cytogenet. United States; 1987;179-80.

61. Lu YJ, Birdsall S, Summersgill B, Smedley D, Osin P, 73. Fisher $\mathrm{C}$, et al. Dual colour fluorescence in situ hybridization to paraffin-embedded samples to deduce the presence of the $\operatorname{der}(\mathrm{X}) \mathrm{t}(\mathrm{X} ; 18)(\mathrm{p} 11.2 ; \mathrm{q} 11.2)$ and involve- 74 . ment of either the SSX1 or SSX2 gene: a diagnostic and prognostic aid for synovial sarcoma. J Pathol England. 1999;187:490-6.

62. Reeves BR, Smith S, Fisher C, Warren W, Knight J, Martin 75. $\mathrm{C}$, et al. Characterization of the translocation between chromosomes $\mathrm{X}$ and 18 in human synovial sarcomas. Oncogene England. 1989;4:373-8.

63. Crew AJ, Clark J, Fisher C, Gill S, Grimer R, Chand A, et al. Fusion of SYT to two genes, SSX1 and SSX2, encoding proteins with homology to the Kruppel- 76 . associated box in human synovial sarcoma. EMBO J. 1995; 14:2333-40.

64. Przybyl J, Sciot R, Rutkowski P, Siedlecki JA, Vanspauwen V, Samson I, et al. Recurrent and novel SS18-SSX 77. fusion transcripts in synovial sarcoma: description of three new cases. Tumour Biol J Int Soc Oncodevelopmental Biol Med. 2012;33:2245-53.

65. Saito T. The SYT-SSX fusion protein and histological 78 . epithelial differentiation in synovial sarcoma: relationship with extracellular matrix remodeling. Int J Clin Exp Pathol e-Century Publishing Corporation. 2013;6:2272-9.

66. Ladanyi M, Antonescu CR, Leung DH, Woodruff JM, Kawai A, Healey JH, et al. Impact of SYT-SSX fusion type on the clinical behavior of synovial sarcoma: a multiinstitutional retrospective study of 243 patients. Cancer 80 . Res United States. 2002;62:135-40.

67. Kawai A, Woodruff J, Healey JH, Brennan MF, Antonescu CR, Ladanyi M. SYT-SSX gene fusion as a determinant of morphology and prognosis in synovial sarcoma. N Engl J Med United States. 1998;338:153-60.

68. Antonescu CR, Kawai A, Leung DH, Lonardo F, Woodruff JM, Healey JH, et al. Strong association of SYT-SSX fusion type and morphologic epithelial differentiation 82 . in synovial sarcoma. Diagn Mol Pathol United States. 2000;9:1-8.

69. Birdsall S, Osin P, Lu Y-J, Fisher C, Shipley J. Synovial sarcoma specific translocation associated with both epithelial and spindle cell components. Int J Cancer. John Wiley \& Sons, Ltd; 1999;82:605-8. Available from: 83. https://doi.org/10.1002/(SICI)1097-0215(19990812) 82:4\%3C605::AID-IJC22\%3E3.0.CO.

70. Takenaka S, Ueda T, Naka N, Araki N, Hashimoto N, Myoui A, et al. Prognostic implication of SYT-SSX fusion type in synovial sarcoma: a multi-institutional 84 . retrospective analysis in Japan. Oncol Rep Greece. 2008;19:467-76.

71. Inagaki H, Nagasaka T, Otsuka T, Sugiura E, Nakashima N, Eimoto T. Association of SYT-SSX fusion types with proliferative activity and prognosis in synovial sarcoma. Mod Pathol an Off J United States Can Acad Pathol Inc United States. 2000;13:482-8.
Haldar M, Randall RL, Capecchi MR. Synovial sarcoma: from genetics to genetic-based animal modeling. Clin Orthop Relat Res. 2008;466:2156-67.

Ren T, Lu Q, Guo W, Lou Z, Peng X, Jiao G, et al. The clinical implication of SS18-SSX fusion gene in synovial sarcoma. Br J Cancer. 2013;109:2279-85.

Speth BM, Krieg AH, Kaelin A, Exner GU, Guillou L, von Hochstetter A, et al. Synovial sarcoma in patients under 20 years of age: a multicenter study with a minimum follow-up of 10 years. J Child Orthop. 2011;5:335-42. Zaborowski M, Vargas AC, Pulvers J, Clarkson A, de Guzman D, Sioson L, et al. When used together SS18-SSX fusion-specific and SSX C-terminus immunohistochemistry are highly specific and sensitive for the diagnosis of synovial sarcoma and can replace FISH or molecular testing in most cases. Histopathology. England; 2020. Ten Heuvel SE, Hoekstra HJ, Suurmeijer AJH. Diagnostic accuracy of FISH and RT-PCR in 50 routinely processed synovial sarcomas. Appl Immunohistochem Mol Morphol AIMM United States. 2008;16:246-50.

Vargas AC, Selinger C, Satgunaseelan L, Cooper WA, Gupta R, Stalley P, et al. FISH analysis of selected soft tissue tumors: diagnostic experience in a tertiary center. Asia Pac J Clin Oncol Australia. 2019;15:38-47.

Papp G, Mihály D, Sápi Z. Unusual signal patterns of break-apart fish probes used in the diagnosis of soft tissue sarcomas. Pathol Oncol Res Switzerland. 2017;23:863-71.

79. Hale R, Sandakly S, Shipley J, Walters Z. Epigenetic targets in synovial sarcoma: a mini-review. Front Oncol. 2019;9:1078. Available from: https://www.frontiersin. org/article/10.3389/fonc.2019.01078.

El Beaino M, Araujo DM, Lazar AJ, Lin PP. Synovial sarcoma: advances in diagnosis and treatment identification of new biologic targets to improve multimodal therapy. Ann Surg Oncol United States. 2017;24:2145-54

81. Filippi RZ, Swee RG, Unni KK. Epithelioid multinodular osteoblastoma: a clinicopathologic analysis of 26 cases. Am J Surg Pathol LWW. 2007;31:1265-8.

Lagarde P, Przybyl J, Brulard C, Pérot G, Pierron G, Delattre $\mathrm{O}$, et al. Chromosome instability accounts for reverse metastatic outcomes of pediatric and adult synovial sarcomas. J Clin Oncol. Wolters Kluwer; 2013;31:608-15. Available from: https://doi.org/10. 1200/JCO.2012.46.0147.

Limon J, Mrozek K, Mandahl N, Nedoszytko B, Verhest A, Rys J, et al. Cytogenetics of synovial sarcoma: presentation of ten new cases and review of the literature. Genes Chromosomes Cancer United States. 1991;3:338-45.

Sandberg AA, Bridge JA. The cytogenetics of bone and soft tissue tumors. RG Landes Company; 1994.

85. Centore RC, Sandoval GJ, Soares LMM, Kadoch C, Chan HM. Mammalian SWI/SNF chromatin remodeling complexes: emerging mechanisms and therapeutic strategies. Trends Genet. Elsevier; 2020;36:936-50. Available from: https://doi.org/10.1016/j.tig.2020.07.011. 
86. Chittock EC, Latwiel S, Miller TCR, Müller CW. Molecular architecture of polycomb repressive complexes. Biochem Soc Trans. 2017;45:193-205.

87. Roberts CWM, Orkin SH. The SWI/SNF complexchromatin and cancer. Nat Rev Cancer England. 2004;4:133-42.

88. Peterson CL, Herskowitz I. Characterization of the 102 yeast SWI1, SWI2, and SWI3 genes, which encode a global activator of transcription. Cell United States. 1992;68:573-83.

89. Hirschhorn JN, Brown SA, Clark CD, Winston F. Evidence that SNF2/SWI2 and SNF5 activate transcription in yeast by altering chromatin structure. Genes Dev United States. 1992;6:2288-98.

90. Thaete C, Brett D, Monaghan P, Whitehouse S, Rennie G, Rayner E, et al. Functional domains of the SYT and SYT-SSX synovial sarcoma translocation proteins and co-localization with the SNF protein BRM in the nucleus. Hum Mol Genet England. 1999;8:585-91.

91. Kadoch C, Crabtree GR. Reversible disruption of mSWI/ SNF (BAF) complexes by the SS18-SSX oncogenic fusion in synovial sarcoma. Cell. 2013;153:71-85.

92.• Nacev BA, Jones KB, Intlekofer AM, Yu JSE, Allis CD, Tap WD, et al. The epigenomics of sarcoma. Nat Rev Cancer. England; 2020;20:608-23.

An overview of the current evidence regarding disorders in epigenetic regulation found in sarcomas.

93. McBride MJ, Pulice JL, Beird HC, Ingram DR, D'Avino AR, Shern JF, et al. The SS18-SSX fusion oncoprotein hijacks BAF complex targeting and function to drive synovial sarcoma. Cancer Cell. 2018;33:1128-1141.e7.

94. de Bruijn DRH, Allander SV, van Dijk AHA, Willemse MP, Thijssen J, van Groningen JJM, et al. The synovialsarcoma-associated SS18-SSX2 fusion protein induces epigenetic gene (de)regulation. Cancer Res United States. 2006;66:9474-82.

95. Soulez M, Saurin AJ, Freemont PS, Knight JC. SSX and the synovial-sarcoma-specific chimaeric protein SYTSSX co-localize with the human polycomb group complex. Oncogene England. 1999;18:2739-46.

96. Ishida A, Asano H, Hasegawa M, Koseki H, Ono T, Yoshida MC, et al. Cloning and chromosome mapping of the human Mel-18 gene which encodes a DNAbinding protein with a new "RING-finger" motif. Gene Netherlands. 1993;129:249-55.

97. Gao Z, Zhang J, Bonasio R, Strino F, Sawai A, Parisi F, et al. PCGF homologs, CBX proteins, and RYBP define functionally distinct PRC1 family complexes. Mol Cell. 2012/02/14. 2012;45:344-56.

98. Poynter ST, Kadoch C. Polycomb and trithorax opposition in development and disease. Wiley Interdiscip Rev Dev Biol. 2016;5:659-88.

99. Barco R, Garcia CB, Eid JE. The synovial sarcoma-associated SYT-SSX2 oncogene antagonizes the polycomb complex protein Bmi1. PLoS One. Public Library of Science; 2009;4:e5060. Available from: https://doi.org/10. 1371/journal.pone.0005060.

100. Astolfi A, Fiore M, Melchionda F, Indio V, Bertuccio SN, 113 Pession A. BCOR involvement in cancer. Epigenomics.
2019. p. 835-55. Available from: https://www.futur emedicine.com/doi/10.2217/epi-2018-0195.

Banito A, Li X, Laporte AN, Roe J-S, Sanchez-Vega F, Huang C-H, et al. The SS18-SSX oncoprotein hijacks KDM2B-PRC1.1 to drive synovial sarcoma. Cancer Cell. 2018;33:527-541.e8.

Richly H, Aloia L, Di Croce L. Roles of the polycomb group proteins in stem cells and cancer. Cell Death Dis. 2011;2:e204.

103. Su L, Sampaio A V, Jones KB, Pacheco M, Goytain A, Lin $\mathrm{S}$, et al. Deconstruction of the SS18-SSX fusion oncoprotein complex: insights into disease etiology and therapeutics. Cancer Cell. 2012;21:333-47. Available from: https://pubmed.ncbi.nlm.nih.gov/22439931.

Jones KB, Su L, Jin H, Lenz C, Randall RL, Underhill TM, et al. SS18-SSX2 and the mitochondrial apoptosis pathway in mouse and human synovial sarcomas. Oncogene. 2013;32(2365-71):2375.e1-5.

105. Garcia CB, Shaffer CM, Eid JE. Genome-wide recruitment to Polycomb-modified chromatin and activity regulation of the synovial sarcoma oncogene SYT-SSX2. BMC Genomics. 2012;13:189.

106. Shen JK, Cote GM, Gao Y, Choy E, Mankin HJ, Hornicek FJ, et al. Targeting EZH2-mediated methylation of H3K27 inhibits proliferation and migration of synovial sarcoma in vitro. Sci Rep. 2016;6:25239.

107. Fernebro J, Francis P, Edén P, Borg A, Panagopoulos I, Mertens F, et al. Gene expression profiles relate to SS18/SSX fusion type in synovial sarcoma. Int J Cancer United States. 2006;118:1165-72.

108. Przybyl J, Jurkowska M, Rutkowski P, Debiec-Rychter $M$, Siedlecki JA. Downstream and intermediate interactions of synovial sarcoma-associated fusion oncoproteins and their implication for targeted therapy. Sarcoma. 2012/03/25. Hindawi Publishing Corporation; 2012;2012:249219. Available from: https://pubmed. ncbi.nlm.nih.gov/22550415.

Nilsson G, Skytting B, Xie Y, Brodin B, Perfekt R, Mandahl N, et al. The SYT-SSX1 variant of synovial sarcoma is associated with a high rate of tumor cell proliferation and poor clinical outcome. Cancer Res United States. 1999;59:3180-4.

Baird K, Davis S, Antonescu CR, Harper UL, Walker $\mathrm{RL}$, Chen Y, et al. Gene expression profiling of human sarcomas: insights into sarcoma biology. Cancer Res. 2005; 65:9226 LP - 9235. Available from: http://cance rres.aacrjournals.org/content/65/20/9226.abstract. Nakayama R, Mitani S, Nakagawa T, Hasegawa T, Kawai A, Morioka $\mathrm{H}$, et al. Gene expression profiling of synovial sarcoma: distinct signature of poorly differentiated type. Am J Surg Pathol United States. 2010;34:1599-607.

Sekiya T, Zaret KS. Repression by Groucho/TLE/Grg proteins: genomic site recruitment generates compacted chromatin in vitro and impairs activator binding in vivo. Mol Cell. Elsevier; 2007;28:291-303. Available from: https://doi.org/10.1016/j.molcel.2007.10.002. Jennings BH, Pickles LM, Wainwright SM, Roe SM, Pearl LH, Ish-Horowicz D. Molecular recognition of 
transcriptional repressor motifs by the WD domain of 127 . the Groucho/TLE corepressor. Mol Cell United States. 2006;22:645-55.

114. Jennings BH, Ish-Horowicz D. The groucho/TLE/Grg family of transcriptional co-repressors. Genome Biol. 2008;9:205. Available from: https://doi.org/10.1186/ 128. gb-2008-9-1-205.

115. Yuan D, Yang X, Yuan Z, Zhao Y, Guo J. TLE1 function and therapeutic potential in cancer. Oncotarget. Impact Journals LLC; 2017;8:15971-6. Available from: https:// pubmed.ncbi.nlm.nih.gov/27852056.

116. Terry J, Saito T, Subramanian S, Ruttan C, Antonescu CR, Goldblum JR, et al. TLE1 as a diagnostic immunohistochemical marker for synovial sarcoma emerging from gene expression profiling studies. Am J Surg Pathol United States. 2007;31:240-6.

117. Nielsen TO, Poulin NM, Ladanyi M. Synovial sarcoma: 130. recent discoveries as a roadmap to new avenues for therapy. Cancer Discov. 2015;5:124-34.

118. El Beaino M, Jupiter DC, Assi T, Rassy E, Lazar AJ, Araujo DM, et al. Diagnostic value of TLE1 in synovial sar- 131 . coma: a systematic review and meta-analysis. Sarcoma. 2020;2020:7192347.

119. Hisaoka M, Matsuyama A, Nagao Y, Luan L, Kuroda T, Akiyama $\mathrm{H}$, et al. Identification of altered MicroRNA expression patterns in synovial sarcoma. Genes Chro- 132. mosomes Cancer United States. 2011;50:137-45.

120. Foo WC, Cruise MW, Wick MR, Hornick JL. Immunohistochemical staining for TLE1 distinguishes synovial sarcoma from histologic mimics. Am J Clin Pathol England. 2011;135:839-44.

121. Jagdis A, Rubin BP, Tubbs RR, Pacheco M, Nielsen TO. 133. Prospective evaluation of TLE1 as a diagnostic immunohistochemical marker in synovial sarcoma. Am J Surg Pathol United States. 2009;33:1743-51.

122. Kosemehmetoglu K, Vrana JA, Folpe AL. TLE1 expression is not specific for synovial sarcoma: a whole sec- 134 . tion study of 163 soft tissue and bone neoplasms. Mod Pathol an Off J United States Can Acad Pathol Inc United States. 2009;22:872-8.

123. Valente AL, Tull J, Zhang S. Specificity of TLE1 expression in unclassified high-grade sarcomas for the diagnosis of synovial sarcoma. Appl Immunohistochem Mol Morphol AIMM United States. 2013;21:408-13.

124. Matsuyama A, Hisaoka M, Iwasaki M, Iwashita $M$, Hisanaga $S$, Hashimoto $H$. TLE1 expression in malignant mesothelioma. Virchows Arch Germany. 2010;457:577-83.

125. Pelmus M, Guillou L, Hostein I, Sierankowski G, Lussan C, Coindre J-M. Monophasic fibrous and poorly differentiated synovial sarcoma: immunohistochemical reassessment of $60 \mathrm{t}(\mathrm{X} ; 18)$ (SYT-SSX)-positive cases. Am J Surg Pathol United States. 2002;26:1434-40.

126. Zaccarini DJ, Deng X, Tull J, Maciak C, Valente AL, Zhang S. Expression of TLE-1 and CD99 in carcinoma: pitfalls in diagnosis of synovial sarcoma. Appl Immunohistochem Mol Morphol AIMM United States. 2018;26:368-73.
He X, Xiong B, Zhou T, Lan T, Chen M, Chen H, et al. Diagnostic value of TLE1 for synovial sarcoma: immunohistochemical analyses of genetically confirmed synovial sarcomas and nonsynovial sarcomas. Int J Clin Exp Pathol. 2016;9:4339-50.

Jungbluth AA, Antonescu CR, Busam KJ, Iversen K, Kolb D, Coplan K, et al. Monophasic and biphasic synovial sarcomas abundantly express cancer/testis antigen NYESO-1 but not MAGE-A1 or CT7. Int J Cancer United States. 2001;94:252-6.

129. Lai J-P, Robbins PF, Raffeld M, Aung PP, Tsokos M, Rosenberg SA, et al. NY-ESO-1 expression in synovial sarcoma and other mesenchymal tumors: significance for NY-ESO-1-based targeted therapy and differential diagnosis. Mod Pathol Off J United States Can Acad Pathol Inc. 2012;25:854-8.

Rekhi B, Sable M, Jambhekar NA. Histopathological, immunohistochemical and molecular spectrum of myoepithelial tumours of soft tissues. Virchows Arch Germany. 2012;461:687-97.

Kohashi K, Oda Y, Yamamoto H, Tamiya S, Matono H, Iwamoto Y, et al. Reduced expression of SMARCB1/ INI1 protein in synovial sarcoma. Mod Pathol an Off J United States Can Acad Pathol Inc United States. 2010;23:981-90.

Keith JL, Bilbao J, Croul S, Ang LC, Guiot M-C, Rossiter J, et al. Clinical Neuropathology practice guide 6-2013: morphology and an appropriate immunohistochemical screening panel aid in the identification of synovial sarcoma by neuropathologists. Clin Neuropathol. 2013;32:461-70.

Fisher C. Synovial sarcoma: ultrastructural and immunohistochemical features of epithelial differentiation in monophasic and biphasic tumors. Hum Pathol. 1986;17:996-1008. Available from: https://www.scien cedirect.com/science/article/pii/S0046817786800831. Abenoza P, Manivel JC, Swanson PE, Wick MR. Synovial sarcoma:: ultrastructural study and immunohistochemical analysis by a combined peroxidase-antiperoxidase/avidin-biotin-peroxidase complex procedure. Hum Pathol. 1986;17:1107-15. Available from: https:// www.sciencedirect.com/science/article/pii/S004681778 6804154 .

135. Jørgensen LJ, Lyon H, Myhre-Jensen O, Nordentoft A, Sneppen O. Synovial sarcoma. An immunohistochemical study of the epithelial component. APMIS Denmark. 1994;102:191-6.

136. Hornick JL, Fletcher CDM. Myoepithelial tumors of soft tissue: a clinicopathologic and immunohistochemical study of 101 cases with evaluation of prognostic parameters. Am J Surg Pathol United States. 2003;27:1183-96. Miettinen M. Keratin subsets in spindle cell sarcomas. Keratins are widespread but synovial sarcoma contains a distinctive keratin polypeptide pattern and desmoplakins. Am J Pathol. 1991;138:505-13.

Smith TA, Machen SK, Fisher C, Goldblum JR. Usefulness of cytokeratin subsets for distinguishing monophasic synovial sarcoma from malignant peripheral nerve 
sheath tumor. Am J Clin Pathol. 1999;112:641-8. Avail- 153. able from: https://doi.org/10.1093/ajcp/112.5.641.

139. Chuang H-C, Hsu S-C, Huang C-G, Hsueh S, Ng K-F, Chen T-C. Reappraisal of TLE-1 immunohistochemical staining and molecular detection of SS18-SSX fusion transcripts for 154 . synovial sarcoma. Pathol Int Australia. 2013;63:573-80.

140. Ordóñez NG, Mahfouz SM, Mackay B. Synovial sarcoma: an immunohistochemical and ultrastructural study. Hum Pathol. 1990;21:733-49. Available from: https://www. sciencedirect.com/science/article/pii/0046817790900343.

141. Fisher C, Montgomery E, Healy V. Calponin and 155. h-caldesmon expression in synovial sarcoma; the use of calponin in diagnosis. Histopathology England. 2003;42:588-93.

142. Baranov E, McBride MJ, Bellizzi AM, Ligon AH, 156 Fletcher CDM, Kadoch C, et al. A novel SS18-SSX fusion-specific antibody for the diagnosis of synovial sarcoma. Am J Surg Pathol. 2020;44:922-33.

143. Jami SA, Mobarak SAl, Jiandang S, Xi Z, Tanvir MMS, 157. Monilal SS. Clinical and strategic outcomes of metastatic synovial sarcoma on limb. Int J Health Sci (Qassim). 2020;14:38-43.

144. Smolle MA, Parry M, Jeys L, Abudu S, Grimer R. Syno- 158. vial sarcoma: do children do better? Eur J Surg Oncol J Eur Soc Surg Oncol Br Assoc Surg Oncol England. 2019;45:254-60.

145. Palmerini E, Staals EL, Alberghini M, Zanella L, Ferrari 159. C, Benassi MS, et al. Synovial sarcoma: retrospective analysis of 250 patients treated at a single institution. Cancer United States. 2009;115:2988-98.

146. Ferrari A, Bisogno G, Alaggio R, Cecchetto G, Collini 160. $\mathrm{P}$, Rosolen A, et al. Synovial sarcoma of children and adolescents: the prognostic role of axial sites. Eur J Cancer England. 2008;44:1202-9.

147 Thienpont E. Conversion of a unicompartmental knee arthroplasty to a total knee arthroplasty: can we achieve a primary result? Bone Joint J England. 2017;99-B:65-9.

148. Stacchiotti S, Van Tine BA. Synovial sarcoma: current 161. concepts and future perspectives. J Clin Oncol Off J Am Soc Clin Oncol United States. 2018;36:180-7.

149. Xiong L, Chen Z, Zhou Y, Li H, Xiao T. The survival and prognosis analysis of synovial sarcoma subtypes: a Surveillance, Epidemiology, and End Results population- 162. based analysis. Int Orthop Germany. 2020;44:2779-86.

150. Vining CC, Sinnamon AJ, Ecker BL, Kelz RR, Fraker $\mathrm{DL}$, Roses RE, et al. Adjuvant chemotherapy in resectable synovial sarcoma. J Surg Oncol United States. 2017;116:550-8.

151. Gingrich AA, Marrufo AS, Liu Y, Li C-S, Darrow MA, Monjazeb AM, et al. Radiotherapy is associated with improved survival in patients with synovial sarcoma undergoing surgery: A National Cancer Database Analysis. J Surg Res United States. 2020;255:378-87.

152. Canter RJ, Qin L-X, Maki RG, Brennan MF, Ladanyi 164 $M$, Singer S. A synovial sarcoma-specific preoperative nomogram supports a survival benefit to ifosfamidebased chemotherapy and improves risk stratification for patients. Clin cancer Res an Off J Am Assoc Cancer 165. Res. 2008;14:8191-7. von Mehren M, Randall RL, Benjamin RS, Boles S, Bui MM, Conrad EU 3rd, et al. Soft Tissue Sarcoma, Version 2.2016, NCCN Clinical Practice Guidelines in Oncology. J Natl Compr Canc Netw United States. 2016;14:758-86. Yang JC, Chang AE, Baker AR, Sindelar WF, Danforth $\mathrm{DN}$, Topalian SL, et al. Randomized prospective study of the benefit of adjuvant radiation therapy in the treatment of soft tissue sarcomas of the extremity. J Clin Oncol Off J Am Soc Clin Oncol United States. 1998;16:197-203.

Pisters PW, Harrison LB, Leung DH, Woodruff JM, Casper ES, Brennan MF. Long-term results of a prospective randomized trial of adjuvant brachytherapy in soft tissue sarcoma. J Clin Oncol. 1996;14:859-68. Rhomberg W. The radiation response of sarcomas by histologic subtypes: a review with special emphasis given to results achieved with razoxane. Sarcoma. 2006;2006:87367.

Seo SW, Kim J, Son J, Lim S. Evaluation of conditional treatment effects of adjuvant treatments on patients with synovial sarcoma using Bayesian subgroup analysis. BMC Med Inform Decis Mak. 2020;20:320.

Ferrari A, Gronchi A, Casanova M, Meazza C, Gandola L, Collini P, et al. Synovial sarcoma: a retrospective analysis of 271 patients of all ages treated at a single institution. Cancer United States. 2004;101:627-34. Edmonson JH, Ryan LM, Falkson CI, Hicks DG, Blum RH. Phase II study of ifosfamide+doxorubicin in patients with advanced synovial sarcomas (E1793): a Trial of the Eastern Cooperative Oncology Group. Sarcoma. 2003;7:9-11.

Sleijfer S, Ouali M, van Glabbeke M, Krarup-Hansen A, Rodenhuis S, Le Cesne A, et al. Prognostic and predictive factors for outcome to first-line ifosfamide-containing chemotherapy for adult patients with advanced soft tissue sarcomas: an exploratory, retrospective analysis on large series from the European Organization for Research and T. Eur J Cancer England. 2010;46:72-83. Spurrell EL, Fisher C, Thomas JM, Judson IR. Prognostic factors in advanced synovial sarcoma: an analysis of 104 patients treated at the Royal Marsden Hospital. Ann Oncol. Elsevier; 2005;16:437-44. Available from: https://doi.org/10.1093/annonc/mdi082.

Eilber FC, Brennan MF, Eilber FR, Eckardt JJ, Grobmyer SR, Riedel E, et al. Chemotherapy is associated with improved survival in adult patients with primary extremity synovial sarcoma. Ann Surg. 2007;246:105-13. Available from: https://pubmed.ncbi.nlm.nih.gov/17592298. Ferrari A, De Salvo GL, Brennan B, van Noesel MM, De Paoli A, Casanova $M$, et al. Synovial sarcoma in children and adolescents: the European Pediatric Soft Tissue Sarcoma Study Group prospective trial (EpSSG NRSTS 2005). Ann Oncol Off J Eur Soc Med Oncol England. 2015;26:567-72.

Noujaim J, Constantinidou A, Messiou C, Thway K, Miah A, Benson C, et al. Successful ifosfamide rechallenge in soft-tissue sarcoma. Am J Clin Oncol United States. 2018;41:147-51.

Tap WD, Papai Z, Van Tine BA, Attia S, Ganjoo KN, Jones RL, et al. Doxorubicin plus evofosfamide versus 
doxorubicin alone in locally advanced, unresectable or metastatic soft-tissue sarcoma (TH CR-406/SARC021): an international, multicentre, open-label, randomised phase 3 trial. Lancet Oncol. 2017;18:1089-103.

166. Svancárová L, Blay JY, Judson IR, van Hoesel QGCM, 178. van Oosterom AT, le Cesne A, et al. Gemcitabine in advanced adult soft-tissue sarcomas. A phase II study of the EORTC Soft Tissue and Bone Sarcoma Group. Eur J Cancer England. 2002;38:556-9.

167. Okuno S, Edmonson J, Mahoney M, Buckner JC, Frytak $\mathrm{S}$, Galanis E. Phase II trial of gemcitabine in advanced sarcomas. Cancer United States. 2002;94:3225-9.

168. Verweij J, Lee SM, Ruka W, Buesa J, Coleman R, van Hoessel R, et al. Randomized phase II study of docetaxel versus doxorubicin in first- and second-line chemotherapy for locally advanced or metastatic soft tissue sarcomas in adults: a study of the european organization for research and treatment of cancer soft tissue and. J Clin Oncol Off J Am Soc Clin Oncol United States. 2000;18:2081-6.

169. Maki RG, Wathen JK, Patel SR, Priebat DA, Okuno SH, Samuels B, et al. Randomized phase II study of gemcitabine and docetaxel compared with gemcitabine alone in patients with metastatic soft tissue sarcomas: results of sarcoma alliance for research through collaboration study 002 [corrected]. J Clin Oncol Off J Am Soc Clin Oncol United States. 2007;25:2755-63.

170. Sanfilippo R, Dileo P, Blay J-Y, Constantinidou A, Le Cesne A, Benson C, et al. Trabectedin in advanced synovial sarcomas: a multicenter retrospective study from four European institutions and the Italian Rare Cancer Network. Anticancer Drugs. 2015;26:678-81.

171. Le Cesne A, Cresta S, Maki RG, Blay JY, Verweij J, Poveda A, et al. A retrospective analysis of antitumour activity with trabectedin in translocation-related sarcomas. Eur J Cancer England. 2012;48:3036-44.

172. Germano G, Frapolli R, Belgiovine C, Anselmo A, Pesce $\mathrm{S}$, Liguori $\mathrm{M}$, et al. Role of macrophage targeting in the antitumor activity of trabectedin. Cancer Cell United States. 2013;23:249-62.

173. Di Giandomenico S, Frapolli R, Bello E, Uboldi S, Licandro SA, Marchini S, et al. Mode of action of tra- 185. bectedin in myxoid liposarcomas. Oncogene England. 2014;33:5201-10.

174. Verschoor AJ, Gelderblom H. Pneumothorax as adverse event in patients with lung metastases of soft tissue sarcoma treated with pazopanib: a single reference centre case series. Clin. Sarcoma Res. 2014;14.

175. Nakamura T, Matsumine A, Kawai A, Araki N, Goto T, Yonemoto T, et al. The clinical outcome of pazopanib treatment in Japanese patients with relapsed soft tissue sarcoma: a Japanese Musculoskeletal Oncology Group (JMOG) study. Cancer. 2016;122:1408-16.

176. van der Graaf WTA, Blay J-Y, Chawla SP, Kim D-W, BuiNguyen B, Casali PG, et al. Pazopanib for metastatic soft-tissue sarcoma (PALETTE): a randomised, doubleblind, placebo-controlled phase 3 trial. Lancet (London, England) England. 2012;379:1879-86.

177. Kasper B, Sleijfer S, Litière S, Marreaud S, Verweij J, Hodge 188. $\mathrm{RA}$, et al. Long-term responders and survivors on pazopanib for advanced soft tissue sarcomas: subanalysis of two European Organisation for Research and Treatment of Cancer (EORTC) clinical trials 62043 and 62072. Ann Oncol Off J Eur Soc Med Oncol. 2014;25:719-24.

Sleijfer S, Ray-Coquard I, Papai Z, Le Cesne A, Scurr M, Schöffski $P$, et al. Pazopanib, a multikinase angiogenesis inhibitor, in patients with relapsed or refractory advanced soft tissue sarcoma: a phase II study from the European organisation for research and treatment of cancer-soft tissue and bone sarcoma group (EORTC) study 62. J Clin Oncol Off J Am Soc Clin Oncol United States. 2009;27:3126-32.

179. Mir O, Brodowicz T, Italiano A, Wallet J, Blay J-Y, Bertucci $F$, et al. Safety and efficacy of regorafenib in patients with advanced soft tissue sarcoma (REGOSARC): a randomised, double-blind, placebocontrolled, phase 2 trial. Lancet Oncol England. 2016;17:1732-42.

180. Desar IME, Fleuren EDG, van der Graaf WTA. Systemic treatment for adults with synovial sarcoma. Curr Treat Options Oncol. 2018;19:13.

181. Eberst L, Cropet C, Le Cesne A, Pautier P, Penel N, Adenis A, et al. The off-label use of targeted therapies in sarcomas: the OUTC'S program. BMC Cancer. 2014; 14:870.

182. Maki RG, D'Adamo DR, Keohan ML, Saulle M, Schuetze SM, Undevia SD, et al. Phase II study of sorafenib in patients with metastatic or recurrent sarcomas. J Clin Oncol Off J Am Soc Clin Oncol. 2009;27:3133-40.

Hong DS, Garrido-Laguna I, Ekmekcioglu S, Falchook GS, Naing A, Wheler JJ, et al. Dual inhibition of the vascular endothelial growth factor pathway: a phase 1 trial evaluating bevacizumab and AZD2171 (cediranib) in patients with advanced solid tumors. Cancer United States. 2014;120:2164-73.

Berry V, Basson L, Bogart E, Mir O, Blay J-Y, Italiano A, et al. REGOSARC: Regorafenib versus placebo in doxorubicin-refractory soft-tissue sarcoma-a qualityadjusted time without symptoms of progression or toxicity analysis. Cancer. 2017;123:2294-302.

Yoo KH, Kim HS, Lee SJ, Park SH, Kim SJ, Kim SH, et al. Efficacy of pazopanib monotherapy in patients who had been heavily pretreated for metastatic soft tissue sarcoma: a retrospective case series. BMC Cancer. 2015;15:154.

186.• Riedel RF, Jones RL, Italiano A, Bohac C, Thompson JC, Mueller K, et al. Systemic Anti-Cancer Therapy in Synovial Sarcoma: A Systematic Review. Cancers (Basel). 2018;10.

A recent comprehensive review of the current standard of care and future developments regarding systemic treatments of synovial sarcoma.

187. Mi Y-J, Liang Y-J, Huang H-B, Zhao H-Y, Wu C-P, Wang F, et al. Apatinib (YN968D1) reverses multidrug resistance by inhibiting the efflux function of multiple ATP-binding cassette transporters. Cancer Res. 2010;70:7981-91.

Wang Y, Lu M, Zhou Y, Zhou S, Yu X, Tang F, et al. The efficacy and safety of apatinib in advanced synovial 
sarcoma: a case series of twenty-one patients in one single institution. Cancer Manag Res. 2020;12:5255-64.

189. Weigel B, Malempati S, Reid JM, Voss SD, Cho SY, Chen HX, et al. Phase 2 trial of cixutumumab in children, adolescents, and young adults with refractory solid tumors: a report from the Children's Oncology Group. Pediatr Blood Cancer. 2013/08/17. 2014;61:452-6. 202. Available from: https://pubmed.ncbi.nlm.nih.gov/ 23956055.

190. Ho AL, Vasudeva SD, Laé M, Saito T, Barbashina V, Antonescu CR, et al. PDGF receptor alpha is an alternative mediator of rapamycin-induced Akt activation: implications for combination targeted therapy of synovial sarcoma. Cancer Res. 2012;72:4515-25.

191. Fleuren EDG, Vlenterie M, van der Graaf WTA, Hillebrandt-Roeffen MHS, Blackburn J, Ma X, et al. Phosphoproteomic profiling reveals ALK and MET as novel actionable targets across synovial sarcoma subtypes. Cancer Res United States. 2017;77:4279-92.

192. Schoffski P, Agulnik M, Stacchiotti S, Davis LE, Villalobos VM, Italiano A, et al. Phase 2 multicenter study of the EZH2 inhibitor tazemetostat in adults with synovial sarcoma (NCT02601950). J Clin Oncol. Wolters Kluwer; 2017;35:11057. Available from: https://doi.org/10. 206. 1200/JCO.2017.35.15_suppl.11057.

193. Shiloh Y. The ATM-mediated DNA-damage response: taking shape. Trends Biochem Sci England. 2006;31:402-10.

194. Ito T, Ouchida M, Morimoto Y, Yoshida A, Jitsumori Y, 207. Ozaki T, et al. Significant growth suppression of synovial sarcomas by the histone deacetylase inhibitor FK228 in vitro and in vivo. Cancer Lett Ireland. 2005;224:311-9.

195. Watanabe R, Ui A, Kanno S-I, Ogiwara H, Nagase T, Kohno T, et al. SWI/SNF factors required for cellular resistance to DNA damage include ARID1A and 208. ARID1B and show interdependent protein stability. Cancer Res United States. 2014;74:2465-75.

196. Barham W, Frump AL, Sherrill TP, Garcia CB, SaitoDiaz K, VanSaun MN, et al. Targeting the Wnt pathway in synovial sarcoma models. Cancer Discov. 2013;3:1286-301.

197. Trautmann M, Sievers E, Aretz S, Kindler D, Michels $\mathrm{S}$, Friedrichs N, et al. SS18-SSX fusion protein-induced $\mathrm{Wnt} / \beta$-catenin signaling is a therapeutic target in synovial sarcoma. Oncogene England. 2014;33:5006-16.

198. Li Y-X, Ding S-S, Wen W-J, Han L, Wang H-Q, Shi H-Y. 210. Impact of the activation status of the Akt/mTOR signalling pathway on the clinical behaviour of synovial sarcoma: retrospective analysis of 174 patients at a single institution. Cancer Manag Res. 2020;12:1759-69.

199. Xie Y, Skytting B, Nilsson G, Grimer RJ, Mangham CD, Fisher C, et al. The SYT-SSX1 fusion type of synovial sarcoma is associated with increased expression of cyclin A and D1. A link between $\mathrm{t}(\mathrm{X} ; 18)(\mathrm{p} 11.2 ; \mathrm{q} 11.2)$ and the cell cycle machinery. Oncogene England. 2002;21:5791-6.

200. Vlenterie M, Hillebrandt-Roeffen MHS, Schaars EWM, Flucke UE, Fleuren EDG, Navis AC, et al. Targeting cyclin-dependent kinases in synovial sarcoma: palbociclib as a potential treatment for synovial sarcoma patients. Ann Surg Oncol. 2016;23:2745-52.

Wang J, Sato K, O'Donnell E, Singla A, Yaguare S, Aldahamsheh $\mathrm{O}$, et al. Skp2 depletion reduces tumor-initiating properties and promotes apoptosis in synovial sarcoma. Transl Oncol United States. 2020;13:100809. Penn I. Sarcomas in organ allograft recipients. Transplantation United States. 1995;60:1485-91.

Pollack SM, He Q, Yearley JH, Emerson R, Vignali M, Zhang Y, et al. T-cell infiltration and clonality correlate with programmed cell death protein 1 and programmed death-ligand 1 expression in patients with soft tissue sarcomas. Cancer. 2017;123:3291-304.

204. Jerby-Arnon L, Neftel C, Shore ME, Weisman HR, Mathewson ND, McBride MJ, et al. Opposing immune and genetic mechanisms shape oncogenic programs in synovial sarcoma. Nat Med United States. 2021;27:289-300.

205. Lewis JJ, Antonescu CR, Leung DH, Blumberg D, Healey JH, Woodruff JM, et al. Synovial sarcoma: a multivariate analysis of prognostic factors in 112 patients with primary localized tumors of the extremity. J Clin Oncol Off J Am Soc Clin Oncol United States. 2000;18:2087-94. Martín-Broto J, Moura DS, Van Tine BA. Facts and hopes in immunotherapy of soft-tissue sarcomas. Clin Cancer Res. 2020;26:5801 LP - 5808. Available from: http:// clincancerres. aacrjournals.org/content/26/22/5801. abstract.

Pollack SM. The potential of the CMB305 vaccine regimen to target NY-ESO-1 and improve outcomes for synovial sarcoma and myxoid/round cell liposarcoma patients. Expert Rev Vaccines. 2017/12/27. 2018;17:107-14. Available from: https://pubmed.ncbi. nlm.nih.gov/29280411.

Robbins PF, Morgan RA, Feldman SA, Yang JC, Sherry $\mathrm{RM}$, Dudley ME, et al. Tumor regression in patients with metastatic synovial cell sarcoma and melanoma using genetically engineered lymphocytes reactive with NY-ESO-1. J Clin Oncol Off J Am Soc Clin Oncol. 2011;29:917-24.

209. Bean GR, Kremer JC, Prudner BC, Schenone AD, Yao $\mathrm{J}$-C, Schultze MB, et al. A metabolic synthetic lethal strategy with arginine deprivation and chloroquine leads to cell death in ASS1-deficient sarcomas. Cell Death Dis. 2016;7:e2406.

Kremer JC, Prudner BC, Lange SES, Bean GR, Schultze $\mathrm{MB}$, Brashears $\mathrm{CB}$, et al. Arginine deprivation inhibits the warburg effect and upregulates glutamine anaplerosis and serine biosynthesis in ASS1-deficient cancers. Cell Rep. 2017;18:991-1004.

\section{Publisher's Note}

Springer Nature remains neutral with regard to jurisdictional claims in published maps and institutional affiliations. 